\title{
COLONIZATION OF ARTIFICIAL SUBSTRATES BY EPHEMEROPTERA: FIRST STAGES
}

P. Pinto, M. Morais*

Departamento de Biologia, Universidade de Evora, Largo dos Colegiais P-7001 EVORA CODEX

*J.N.I.C.T. Scholarship

Keywords: Macroinvertebrates, Ephemeroptera, Colonization, Artificial substrates, Temporary river

\section{ABSTRACT}

In order to evaluate the colonization in a temporary river, a sampling program was designed in 6 collecting places all along the river Degebe (Guadiana basin) during 1988 in Winter, Spring, Summer and Autumn.

Mesh bags filled with $2500 \mathrm{~cm}^{3}$ of brickbad were used as artificial subst rates.

Cloen schoenemundi, Cloen simile, Caenis Iuctuosa, and Choroterpes picteti were the most abundant species.

The propensity of Ephemeroptera species to colonize the artificial substrates by drift as well as by movements over the substrate is discussed.

\section{INTRODUCTION}

The "stream macroinvertebrates communities are structured assemblages of individual populations in a state of dynamic equilibrium" (Minshall \& Hildrew, 1985). At the same time, a loss of organisms into the water colum is accompanied by a permanent recolonization of the bottom, thus, contributing for a continuous redistribution of the stream benthos (Townsend \& Hildrew, 1976).

The denuded areas of the stream bed can be colonized by drift as well as by movements over the substrate (Bird \& Hynes, 1981; Townsend \& Hildrew, 1976). Although Benzie (1984) results point out to a random nature of the colonization, drift seems to be the most important one (Bishop \& Hynes, 1969; Elliot, 1971; Townsend \& Hildrew, 1976; Bird \& Hynes, 1981).

The propensity of the different taxa for moving in drift or over the substrate is different (Bournaud et al, 1978; Townsend \& Hildrew, 1976; Hart \& Resh, 1980; Bird \& Hynes, 1981). The propose of this study is to evaluate the relative importance of these two behaviours on the colonization process, for Ephemeroptera species.

\section{THE STUDY AREA}

The River Degebe is a tributary of River Guadiana. It flows from Northwest to Southeast for c. $79 \mathrm{~km}$. The difference in altitude between spring and mouth is c. $250 \mathrm{~m}(325 \mathrm{~m}$ vs. $75 \mathrm{~m})$ which mean an average slope of $3 \%$.

The river flow shows a wide variation all over the year, with winter flood and Summer flow interruptions clearly connected with the well marked seasonally of rainy and dry periods.

\section{MATERIAL AND METHODS}

The colonization experiments took place in 6 collecting places all along the river, and covering 6 different ecological situations (fig.1).

- A, a peneplain area without riparian vegetation and presence of macrophytes; 


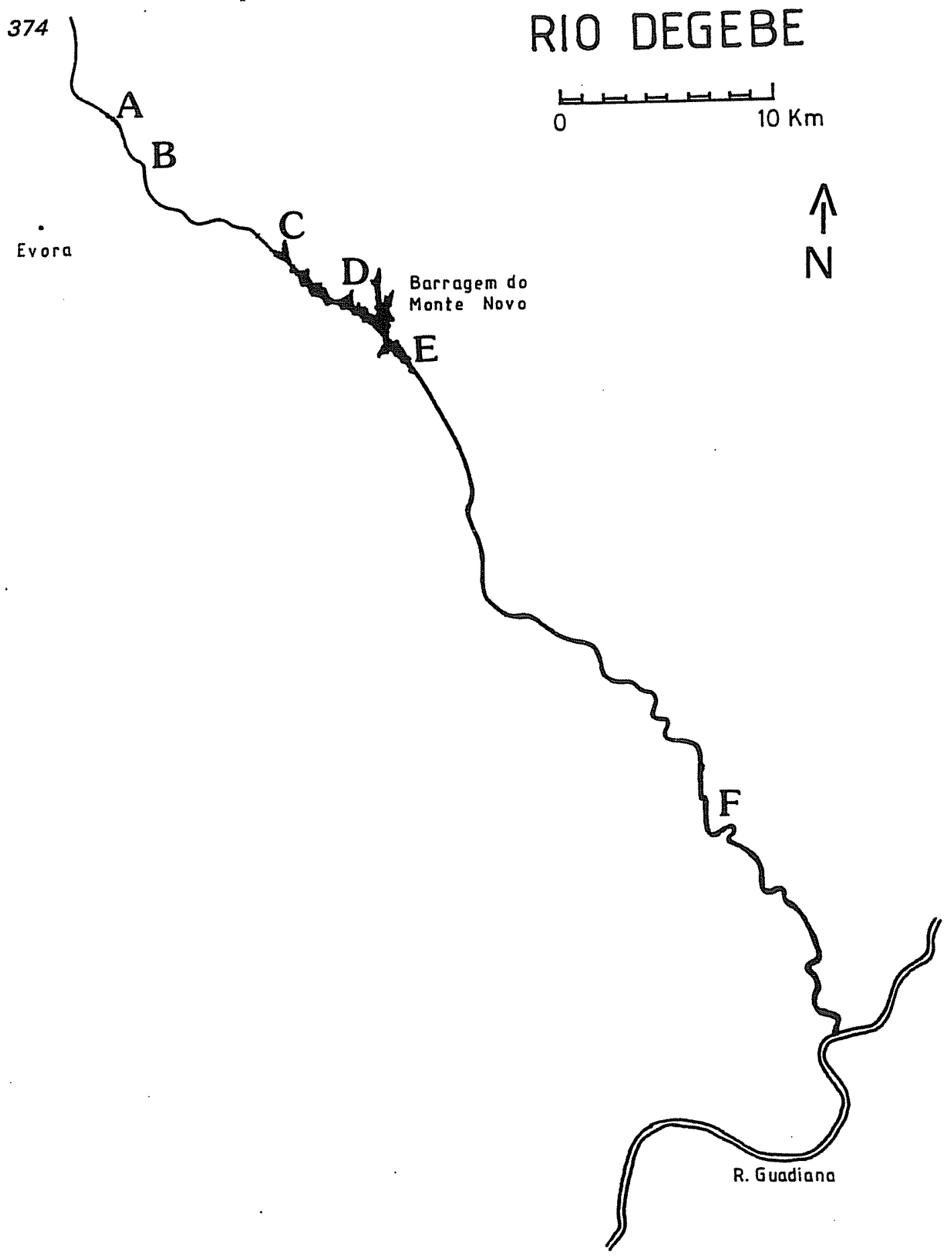

Fig.1. Study area with the 6 collecting places. 
- B, a canopy area;

- C, a shifting feature between lotic and lentic ecosystem;

- D, a lentic ecosystem;

- E, an area with riparian vegetation, macrophytes and wood debris, just downstream the dam;

- F, an area with rocky slopes almost without riparian vegetation and macrophytes.

The study was carried out during 1988 in Winter, Spring, Summer and Autumn.

Mesh bags filled with $2500 \mathrm{~cm}^{3}$ of brickbad $(6 \times 8 \mathrm{~cm})$ were used as artificial substrates. In order to evaluate the way of colonization, two artificial substrates were used: one on the bottom (B) and the other on a support (S) which enables the contact with the bottom.

During one month 15 samples were performed, in each season and collecting place. The two artificial substrates were removed, brushed to plastic containers, sieved with a special designed device and the macroinvertebrates preserved with a $40 \%$ formalin solution. The two artificial substrates were replaced again on the river bed.

The bottom substrate (B) is colonized by drift as well as by movements over the substrate, while the suspended one $(S)$ is colonized by drift only. The the bot tom substrate (B) represents the total colonization, so the average ratio of the number of macroinvertebrates present on the suspended substrate to those from the bottom substrate $(\mathrm{S} / \mathrm{B})$ is the mean drift proportion involved in the colonization (Townsend \& Hildrew, 1976).

\section{RESULTS}

In the table 1 , the results concerning the number of individuals in the suspended (S) and bottom (B) substrates for Ephemeroptera taxa all along the year are presented.

\begin{tabular}{|c|c|c|c|c|c|}
\hline & & HINTER & SPRING & SUMMER & AUIUN \\
\hline Baet is fuscatus & $\begin{array}{l}\text { S } \\
\text { B }\end{array}$ & $\begin{array}{l}15 \\
12\end{array}$ & $\begin{array}{l}78 \\
79\end{array}$ & $=$ & $\begin{array}{l}2 \\
6\end{array}$ \\
\hline Cloen schoenemundi & $\begin{array}{l}\text { S } \\
\text { B }\end{array}$ & $\begin{array}{l}7 \\
5\end{array}$ & $\begin{array}{l}99 \\
70\end{array}$ & $\begin{array}{l}33 \\
40\end{array}$ & $\begin{array}{l}3 \\
2\end{array}$ \\
\hline Cloen simile & $\begin{array}{l}\mathbf{S} \\
\mathbf{B}\end{array}$ & $\begin{array}{l}4 \\
4\end{array}$ & $\begin{array}{l}73 \\
45\end{array}$ & $\begin{array}{c}98 \\
132\end{array}$ & $\begin{array}{c}2 \\
14\end{array}$ \\
\hline Procloen sp. & $\begin{array}{l}\mathrm{S} \\
\mathrm{B}\end{array}$ & $\begin{array}{l}4 \\
3\end{array}$ & $\begin{array}{l}17 \\
28\end{array}$ & $\begin{array}{c}7 \\
12\end{array}$ & $\begin{array}{l}9 \\
4\end{array}$ \\
\hline Caenis luctuosa & $\begin{array}{l}\mathbf{S} \\
\mathbf{B}\end{array}$ & $\begin{array}{l}45 \\
31\end{array}$ & $\begin{array}{l}310 \\
434\end{array}$ & $\begin{array}{l}1045 \\
1309\end{array}$ & $\begin{array}{l}469 \\
522\end{array}$ \\
\hline Choroterpes picteti & $\begin{array}{l}\mathbf{S} \\
\mathrm{B}\end{array}$ & $\begin{array}{l}5 \\
4\end{array}$ & $\begin{array}{l}53 \\
60\end{array}$ & $\begin{array}{l}73 \\
81\end{array}$ & $=$ \\
\hline Thraullus bellus & $\begin{array}{l}\text { S } \\
B\end{array}$ & 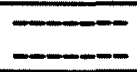 & $\begin{array}{l}7 \\
1\end{array}$ & $\begin{array}{l}9 \\
9\end{array}$ & $\begin{array}{l}1 \\
2\end{array}$ \\
\hline Habrophlebia cf. lauta & $\begin{array}{l}\mathrm{S} \\
\mathrm{B}\end{array}$ & - & $\begin{array}{l}1 \\
3\end{array}$ & $\overline{-}$ & - \\
\hline
\end{tabular}

Table 1: number of individuals in the suspended (S) and bottom (B) substrates all along the year.

As whole, Spring and Summer present the greatest values of number of individuals, confirming previous results (Pinto, 1988). For all the seasons, Caenis luctuosa is the most abundant taxa.

Thraullus bellus and Habrophlebia cf. lauta were excluded from this study, due to its reduced numbers. 
DISCUSSION

Confirming the results of Bird \& Hynes (1980) and Townsend \& Hildrew (1976), the Ephemeroptera taxa, excluding Cloen simile in Autum, present (S/B) ratio values higher than 0,5 , which denote a propensity to colonize the substrates by drift (see table 2 ).

\begin{tabular}{|c|c|c|c|c|c|c|}
\hline & WINTER & SPRING & SUMMER & AUTUMN & $\begin{array}{c}\text { mean } \\
\mathrm{S} / \mathrm{B}\end{array}$ & S.E. \\
\hline $\begin{array}{l}\text { Baet is fuscatus } \\
\text { Cloen schoenemundi } \\
\text { Cloen simile } \\
\text { Procloen sp. } \\
\text { Caenis luctuosa } \\
\text { Choroterpes picteti }\end{array}$ & $\begin{array}{l}1,25 \\
1,40 \\
1,00 \\
1,30 \\
1,45 \\
1,25\end{array}$ & $\begin{array}{l}1,14 \\
1,40 \\
1,62 \\
0,61 \\
0,71 \\
0,88\end{array}$ & $\begin{array}{l}0,82 \\
0,74 \\
0,58 \\
0,79 \\
0,91\end{array}$ & $\begin{array}{l}0,33 \\
1,50 \\
0,14 \\
2,25 \\
0,90 \\
\end{array}$ & $\begin{array}{l}0,91 \\
1,28 \\
0,87 \\
1,19 \\
0,96 \\
1,01\end{array}$ & $\begin{array}{l}0,36 \\
0,18 \\
0,35 \\
0,45 \\
0,19 \\
0,15\end{array}$ \\
\hline $\begin{array}{l}\text { mean } \mathrm{S} / \mathrm{B} \\
\mathrm{S.E}\end{array}$ & $\begin{array}{l}1,28 \\
0,07\end{array}$ & $\begin{array}{l}1,06 \\
0,17\end{array}$ & $\begin{array}{l}0,77 \\
0,06\end{array}$ & $\begin{array}{l}1,02 \\
0,39\end{array}$ & & \\
\hline
\end{tabular}

Table 2: (S/B) ratio values for the different seasons and its mean values for each taxa and each season. (S.E. = Standard error).

Bird \& Hynes (1980) point out (S/B) ratio values between 0,89 and 0,94 for Ephemeroptera taxa. The wide of variation in this study bigger $(0,58-2,25)$, probably as a result of the heterogeneity of the ecological situations.

The low value for $c$. simile in Autum may result from an aggregated distribution of the community at collecting place A. With some more samples, this value will be certainly higher.

The higher mean value of (S/B) ratio in Winter, and the lowest one in Summer, according to previous works (Dimond, 1967; Waters 1969; Elliot,1971; Bird Hynes, 1981; Ciborowski, 1987), suggests a positive correlation between the current and the drift.

The drift seems to be the most important way of colonization, even during the Summer with absent current. An accentuated influence of the swimming behaviour on the colonization process during Summer (58\% to $91 \%$ ), is emphasized by those results. A respiratory stress due to the low values o dissolved oxygen in Summer will be, probably, an explanation to this situation (Minshall \& Winger, 1968; Wi ley \& Kohler, 1980).

\section{REFERENCES}

Benzie, J.A.H..1984. The colonization mechanism of stream benthos in a tropical river (Menik Ganga: Sri Lanka). Hydrobiologia 111. 171-179

Bird, G.A. \& H.B.N. Hynes.1981 - Movements of immature aquatic insects in a lotic habitat. Hydrobiologia 77. 103-112

Bishop, J.E. \& H.B.N. Hynes.1969. Upstream movements of benthic invertebrate in a speed river.J. Fish. Res. Board. Can. 26. 279-298

Bournaud, M.; G. Chavanon et H. Tachet.1978. Colonization par les macroinvertebrés de substrats artificiels suspendus en plein eau ou disposés sur le fond. Verh. Internat. Verein. Limnol. 20. 1485-1493

Ciborowski, J.H..1987. Dynamics of drifting and microdistribution of two may fly 
populations: a predictive model. Can. J. Fish. Aquat. Sci. 44. 832-845

Dimond, J.B..1967. Evidence that drift of stream benthos is density related. Ecology 48. 855-857

Elliot, J.M..1971. Upstream movements of benthic invertebrates in a lake district stream. J. Anim. Ecol. 40. 235-252

Hart, D.D. \& V.H. Resh.1980. Movement patterns and foraging ecology of a stream caddisfly larva. Can. J. Zool. 58. 1174-1185

Minshall, G.W. \& P.V. Winger.1968. The effect of reduction in stream flow on invertebrate drift. Ecology 49. 580-582

Pinto, P..1988. Variaçao anual da estrutura cenótica da ribeira do Degebe (Bacia hidrográfica do Guadiana). Actas Col. Luso-Esp. Ecol. Bacias Hidro. e Rec. Zoológicos 319-326

Townsend, C.R. \& A.G. Hildrew.1976. Field experiments on the drifting colonization and continuous redistribution of stream benthos. I. Anim. Ecol. 45. 759-777

Waters, T.F..1969. Invertebrate drift ecology and significance to stream fishes. Symposium on Salmon and Trout in Streams 121-134

Wiley, M.J. \& S.L. Kohler.1980. Positioning changes of mayfly nymphs due to behavioural regulation of oxygen consumption. Can. J. Zool. 58. 618-622 